\title{
Analysis of the Self-Consumption Regulation for Photovoltaic Systems with Battery Banks in the Portuguese Residential Sector
}

\author{
Sandy Rodrigues, Fábio Faria, Nuno Cafôfo, Xiaoju Chen, Herlander Mata-Lima, and F. Morgado- \\ Dias
}

\begin{abstract}
Following recent trends in the developed countries, Portugal recently cut down the Feed-in tariffs for photovoltaic energy. They are now based on the Iberian market average (around $0.04 € / \mathrm{kWh}$ ) while the final consumer electricity price is $0.16 € / \mathrm{kWh}$. In this view, the PV system should be dimensioned for self-consumption since injecting into the grid produces less revenue. The motivation for the current work was to analyse the changes due to this new regulation, through the analysis of the economic feasibility of different size PV systems $(1 \mathrm{~kW}, 3 \mathrm{~kW}$, and $5 \mathrm{~kW})$, considering the selfconsumption regime with a battery bank as an option. We also compare the most profitable cities in Portugal with and without the use of a battery bank. The results show that the PY systems with battery banks are not as profitable as standalone PV systems in the Portuguese self-consumption regime. This is mainly due to the high price of the battery bank. In general, the mainland results are better than the islands for the $1 \mathrm{~kW}$ and 3kW PV systems. In spite of the higher initial investment cost, the islands present better results for the $5 \mathrm{~kW}$ PV system. In general, it can be stated that the investment in PV systems is highly conditioned by external economical factors that continuously change and the current work analyses the current situation in Portugal for different installed powers with or without battery banks.
\end{abstract}

Index Terms-Battery bank, Grid-tied PV system, IRR, SelfConsumption.

\section{INTRODUCTION}

In most developed countries, the recent trend has been to reduce Feed-in tariffs (FIT) for renewable energy sources, following the decrease in the installation prices and in most cases, the decrease in the economical situation. Portugal was no exception and the FIT for small-scale PV systems (up to $3.68 \mathrm{~kW})$ started in 2008 with a value of $0.65 € / \mathrm{kWh}$ (6 times higher than the final consumer electricity price) and are currently close to $1 / 3$ of that final consumer price [1], [2]. As a result, new PV system installations decreased a lot since 2012. Nevertheless, Portugal has a target to install 720 MW of solar PV systems by 2020 [3].

Recently, in the beginning of 2015, the FIT for the smallscale solar productions were decreased again and are now

Manuscript received June 2, 2015; revised December 23, 2015

Sandy Rodrigues, Fábio Faria, Nuno Cafôfo, and F. Morgado-Dias are with University of Madeira and Madeira Interactive Technologies Institute Funchal, Madeira, Portugal (e-mail: sandy.carmo@m-iti.org, morgado@uma.pt).

Xiaoju Chen is with Civil and Environmental Engineering Department, Carnegie Mellon University, USA.

Herlander Mata-Lima is with CERENA - Technical Institute of Lisbon (IST), University of Lisbon, Portugal. based on the Iberian market value with an average value of approximately $0.04 € / \mathrm{kWh}$. The final consumer electricity price is approximately $0.16 € / \mathrm{kWh}$ (Excluding VAT) which is 4 times higher. Considering this situation, selfconsumption is the fastest way to recover the investment and the regulation also limits the installed power to fulfil the levels of self-consumption [4]. Moreover, the new regulation defines instant net-metering, meaning that selfconsumption is only considered when the energy is being produced at the same instant as it is produced.

Considering the current changes in the regulations we were motivated to analyse if injecting the surplus solar energy into a battery bank would be more profitable than selling it to the grid and analyse also the general profitability under this new regulation. The main objective of this work is therefore to determine whether investing in PV systems in Portugal is still profitable, to determine if it compensates to install a battery bank, and to determine which PV system size and respective city is likely to make the most profit.

In spite of recent changes, battery banks are still expensive where the most common batteries are Lead-Acid and Gel batteries and they can be linked with the PV systems. Currently lead-acid batteries have an 8-year lifecycle while gel batteries have a 12 -year lifecycle. This work considers both battery types [5], [6].

Analysing the Portuguese geography we can see that it includes two overseas sets of islands: the archipelago of Madeira and the archipelago of Azores. In each part, we have considered the highest solar radiation and chose: Aljustrel, Calheta, and Vila do Porto. In these three regions, we can find different electricity tariffs, VAT tax rates, and PV system prices due to transportation and market availability. For the purpose of comparing the different areas, we used the following economic parameters: Internal Rate of Return (IRR), Profitability Index (PI), and the Discounted Payback Period (DPBP) of the Investment.

The paper is composed of the following sections: Methodology, where we describe the techniques used to calculate the economic measures in order to analyse the economic assessment of the PV systems; Results, where the main findings of the data analysis are reported and discussed and Conclusions in the last section.

\section{Methodology}

All methods used to calculate the profit of the investment are explained in this section.

The most common methods to determine the cost- 
effectiveness and economic aspects of this type of project are namely the Internal Rate of Return (IRR), the Discounted Payback Period (DPBP) and the Profitability Index (PI). These methods are used in this work to evaluate the economic feasibility of a $1 \mathrm{~kW}, 3 \mathrm{~kW}$ and a $5 \mathrm{~kW}$ PV system when connected to battery banks or not in Portugal. In the following section, there is a brief description of all the economic methods used in this work.

\section{A. IRR, DPBP, and Profitability Index}

The annual cash flow has to be calculate first by subtracting the cash inflow and the cash outflow, as shown in equation 1 [7], [8] to then proceed to calculate the IRR, the DPBP, and the Profitability Index.

$$
\begin{gathered}
S C F_{y}=\text { Cash in flow }_{y}-\text { Cash out flow }_{y} \\
S C F_{y}=\sum_{y=1}^{Y}(T S \times E s+T e \times E e)_{y}-\sum_{y=1}^{Y}(M)_{y}
\end{gathered}
$$

where $Y$ represents the lifetime of the investment, $T s$ and $T e$ are respectively the self-consumption tariff and the grid injection tariff, $E s$ is the annual electricity $(\mathrm{kWh})$ generated by the PV system used in self-consumption, $E e$ is the electricity produced by the PV system that is then exported into the grid and $M$ is the maintenance cost.

The Discounted Cash Flow (DCF) calculates the time value of money, and it represents the Simple Cash Flow (SCF) value in the future. The interest rate $r$ updates the DCF value as shown on equation 2 .

$$
D C F_{y}=\frac{S C F_{y}}{(1+r)^{y}}
$$

The DPBP uses the DCF values to calculate the number of years needed to breakeven which in turn reflects the value of money over time. In order to evaluate The IRR value it should be compared to a discount or interest rate [9]. A high IRR value indicates that the investment opportunity is favourable, and it should be higher than the discount or interest rate. The IRR has the advantage of considering the time value of money and may be used to compare locations since it does not use the regional discount rates [10]. The IRR formula is presented in equation 3 .

$$
0=\frac{\sum_{y=1}^{Y} C_{y}}{(1+I R R)^{y}}-C_{0}
$$

where $Y$ represents the lifetime of the investment, $C_{y}$ is the yearly net cash flow, $C_{0}$ is the initial investment of the PV system, and $r$ is the interest rate.

The Profitability Index (PI) indicates how much profit or loss the project makes in a certain amount of time. The PI is calculated by dividing the Net Present Value (NPV) of a project by its initial investment and adding 1 , just as shown on equation 4.

The NPV compares all cash inflow present values with all the cash outflow present values of a given investment project. The NPV considers the present money value and is the most accepted standard method used in financial assessments for long-term projects. However, its main drawback lies in the need to assume an interest rate while the IRR does not need to assume an interest rate.

There is a breakeven when PI is equal to 1.00 and when PI is equal to 2.00 the investment is doubled. The lifetime of the investment assumed for this work is 25 years [11].

$$
P I=\frac{\mathrm{NPV}}{\text { Initial Investment }}+1
$$

\section{B. Assumptions}

All the assumption used in this work is explained in this section.

The PV system sizes used in this work are the $1 \mathrm{~kW}$, the $3 \mathrm{~kW}$ and the $5 \mathrm{~kW}$ and all belong to the residential sector. There are two types of self-consumption scenarios $(100 \%$ and $70 \%$ ) and three types of PV systems:

- PV system without a battery bank

- PV system with a lead-acid battery bank

- PV system with a gel battery bank

Portugal has currently an instantaneous net-metering regime, in other words self-consumption only takes place if the energy is consumed at the same instant as it is produced, as opposed to other net-metering systems (see the United States or Brazil) where a monthly balance is made to define the resulting balance between consumption and production. As a result, Portuguese consumers will receive approximately $0.04 € / \mathrm{kWh}$, while paying $0.19 € / \mathrm{kWh}$ (including VAT). The $70 \%$ self-consumption scenario is very likely to occur in Portugal due to this instantaneous net-metering scheme. When the PV system is over-sized, the self-consumption scenario can be much lower than $70 \%$.

The self-consumption (s-c) scenarios for the PV systems are as follows:

- Scenario 1-100\% s-c without batteries;

- Scenario $2-70 \%$ s-c, without batteries;

- Scenario 3-100\% s-c, with lead-acid batteries;

- Scenario 4-70\% s-c, with lead-acid batteries;

- Scenario 5-100\% s-c with gel batteries;

- Scenario 6-70\% s-c with gel batteries.

Both Lead-Acid and Gel batteries are studied in this work and is assumed that the PV system owner does the lead-acid battery maintenance to lower the initial investment values. It is assumed that the autonomy capacity for all the systems is of 1 day (5 hours of consumption) and the Depth of Discharge is $50 \%$ providing a lifecycle of approximately 8 years for the lead-acid batteries and 12 years for the gel batteries [5], [6]. The consumer behaviour determines the relation between the contracted power $(\mathrm{CP})$ and the PV system size because of the instantaneous net-metering scheme that is applied in the self-consumption regime in Portugal. In general, the $\mathrm{CP}$ recommended is the one shown in Table I.

The prices and respective sizes of the battery banks are presented in Table I and are all the same for all the cities in Portugal. Three quotes for each of the battery banks were received from different companies in Portugal. The battery sizes are minimal in order to keep the initial prices low, since their purpose is solely to augment the selfconsumption level of the PV system as grid injection is much less profitable.

The average battery bank cost shown in Table I was used as the battery bank replacement cost in years 10 and 20 in all the regions. 
TABLE I: INFORMATION ABOUT THE BATTERY BANKS

\begin{tabular}{|c|c|c|c|c|c|c|}
\hline 它离 & $\begin{array}{c}\text { CP w/o } \\
\text { Battery } \\
\text { kVA }\end{array}$ & $\begin{array}{c}\text { CP w/ } \\
\text { Battery } \\
\text { kVA }\end{array}$ & $\begin{array}{c}\text { Battery } \\
\text { bank size }\end{array}$ & $\begin{array}{l}\text { Cost } \\
\text { Range }\end{array}$ & $\begin{array}{l}\text { Lead- } \\
\text { Acid } \\
\text { Cost }\end{array}$ & Gel Cost \\
\hline 3 & 10.35 & 3.45 & $\begin{array}{c}2 \mathrm{x} \\
(12 \mathrm{~V} / 250 \mathrm{Ah})\end{array}$ & $\begin{array}{l}\text { Min } \\
\text { Avg. } \\
\text { Max }\end{array}$ & $\begin{array}{l}420 € \\
430 € \\
440 €\end{array}$ & $\begin{array}{l}426.00 € \\
477.33 € \\
506.00 €\end{array}$ \\
\hline$\frac{\vec{m}}{m}$ & 20.7 & 6.9 & $\begin{array}{c}8 x \\
(6 \mathrm{~V} / 250 \mathrm{Ah})\end{array}$ & $\begin{array}{l}\text { Min } \\
\text { Avg. } \\
\text { Max }\end{array}$ & $\begin{array}{l}1.680 € \\
1.720 € \\
1.760 € \\
\end{array}$ & $\begin{array}{l}1,704.00 € \\
1,909.33 € \\
2,024.00 €\end{array}$ \\
\hline$\frac{3}{10}$ & 27.6 & 10.35 & $\begin{array}{c}12 \mathrm{x} \\
(6 \mathrm{~V} / 250 \mathrm{Ah})\end{array}$ & $\begin{array}{l}\text { Min } \\
\text { Avg. } \\
\text { Max }\end{array}$ & $\begin{array}{l}2.520 € \\
2.580 € \\
2.640 €\end{array}$ & $\begin{array}{l}2,556.00 € \\
2,864.00 € \\
3,036.00 €\end{array}$ \\
\hline
\end{tabular}

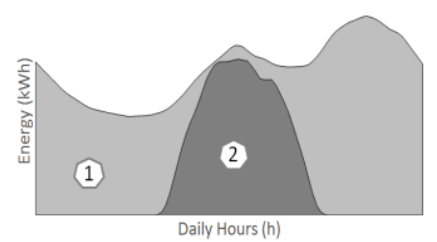

(a) $100 \%$ self-consumption

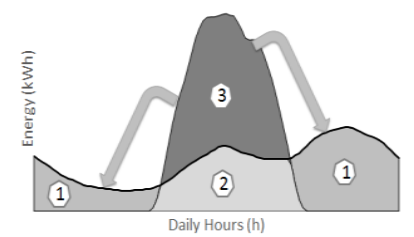

(b) PV system with batteries
Fig. 1. Consumption, self-consumption and battery bank storage. 1 Household consumption / battery bank storage; 2 - Self-consumption / solar production; 3 - Surplus solar production that will be injected into the batteries.

In Portugal the mono and bi-hourly tariff is associated to the contracted power of up to $20.7 \mathrm{kVA}$, the tri-hourly to the contracted powers between $27.6 \mathrm{kVA}$ and $41.4 \mathrm{kVA}$ and tetra-hourly to contracted power superior to $41.4 \mathrm{kVA}$. The mono-hourly tariff is the most beneficial for the PV system connected to a battery bank since the mono-hourly tariff generates the most profit compared to the bi-hourly as the mono-hourly's off-peak tariff is higher than the bi-hourly off-peak tariff. Fig. 1(a) presents a $100 \%$ self-consumption scenario since the solar production and self-consumption takes place within the consumption limit in order to limit grid injection. Fig. 1(b) presents a scenario in which the PV system is connected to a battery bank and the solar production is much higher than the consumption limit of the household therefore forcing the surplus solar production to be injected into the batteries to later be used in the off-peak hours of the day.

Solterm is a PV system dimensioning software developed in Portugal and provides location and climate information of 308 cities in Portugal. Solterm provided information about the location and respective solar production for all the cities of the three regions (mainland, Madeira and Azores) of Portugal that are studied in this paper. 60 cities from the mainland, 10 cities from the island of Madeira and 19 cities from the island of Azores were analysed to choose the one with the highest solar radiation value [12]. However, Solterm's climate information has only one year of data from each of the cities, therefore it was decided that Retscreen software would be used to calculate the correct solar production of each of the PV systems. Retscreen version 4 [13] software is linked to a NASA meteorological database which is calculated based on the monthly average over a 23 year period, therefore making the solar production values more reliable [14]. Climate data of a specific location is calculated by Retscreen if the latitude and longitude coordinates are provided.

The cities that presented the highest horizontal solar radiation values in Retscreen are presented in Fig. 2, and they are namely Aljustrel (mainland) with $5.05 \mathrm{kWh} / \mathrm{m} 2 / \mathrm{d}$, Calheta (Madeira Island) with $5.33 \mathrm{kWh} / \mathrm{m} 2 / \mathrm{d}$ and Vila do Porto (Azores Island) with $4.71 \mathrm{kWh} / \mathrm{m} 2 / \mathrm{d}$. The annual solar production of each of the PV system sizes in all the cities is calculated via Retscreen by first selecting the solar module and inverter type. Then secondly, filling the optimum slope and azimuth values according to the specific city (Aljustrel is $33^{\circ}$, for Calheta is $28^{\circ}$ and for Vila do Porto is $32^{\circ}$ ). Finally, the annual solar production is calculated on Retscreen for both PV system types (with and without battery banks) and the result outcomes are shown in the results section.
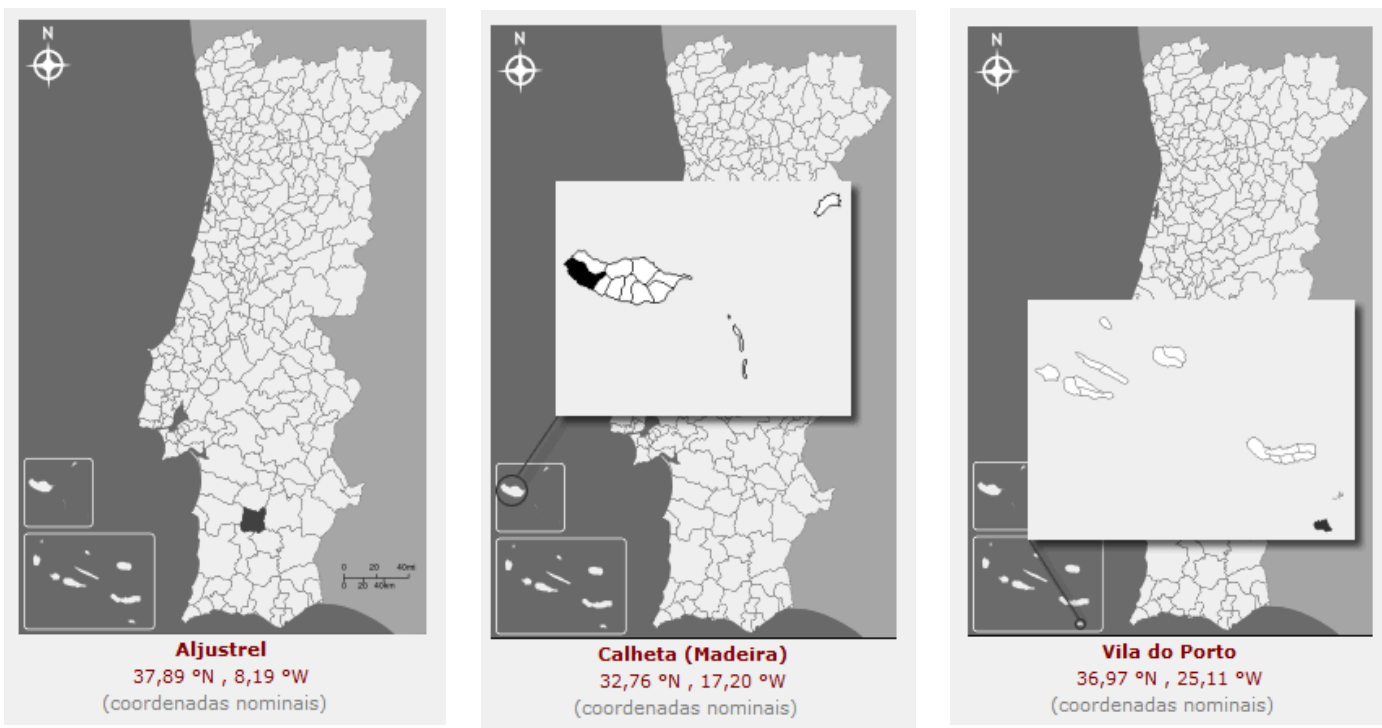

Fig. 2. The cities with the highest solar radiation values in Portugal — Aljustrel (mainland); Calheta (Madeira Island); Vila do Porto (Azores Island).

The battery losses, which can go up to $15 \%$ for the leadacid batteries and a little bit lower for the gel batteries according to [15], are not considered in this work therefore making the final results a little overrated.

All the steps taken to obtain the annual solar production are explained in the following subsections.

\section{1) PV Module and inverter selection}

The selected PV modules (Solar World 245W Polycrystalline) are very efficient and obtained a perfect 
score in the PV+Test2.0 in 2013 according to [16]. The chosen PV module type is crystalline silicon which has a lifecycle within 25-30 years [17], therefore the lifetime of the PV system investment is assumed to be equal to 25 years in this work.

The inverter is the only equipment that is expected to be replaced commonly every 10 years [18], thus assuming the inverter replacement to take place in year 10 and in year 20 in this work.

For the PV systems without batteries the high efficiency inverters selected are the SMA - Sunny boy 1300TL, 3000TL and 5000TL. The efficiency values for the $1 \mathrm{~kW}, 3 \mathrm{~kW}$ and $5 \mathrm{~kW}$ PV systems are respectively $94.3 \%, 96.1 \%$, and $97.5 \%$ [19].

For the three different PV systems connected to a battery bank the Victron Multipuls 24/1200, 24/3000 and the $48 / 5000$ inverters are chosen since they present the best efficiency rates and for the fact that they are hybrid inverters. Hybrid inverters have the advantage of being able to inject the solar energy into both the batteries and/or the grid. The efficiency of the hybrid inverters for each of the PV systems namely the $1 \mathrm{~kW}, 3 \mathrm{~kW}$ and $5 \mathrm{~kW}$ PV systems are $94 \%, 94 \%$, and $95 \%$ respectively [20].

The PV system works by first injecting the solar production into the household grid for self-consumption, to then injecting the surplus energy into the batteries and when these are full and there is no consumption in the household the solar energy is then injected into the distribution grid. The inverter replacement cost rates for each of the PV systems are presented in Table III.

\section{2) Performance ratio (PV system losses)}

It is commonly assumed that performance ratios (PR) for PV systems lie between $75-90 \%$ due to losses generated in the inverter, wiring, and module soiling [21]-[23]. Therefore, a PR value of 0.80 is assumed for this work.

In order to calculate the economical methods (NPV, IRR, DPBP and PI) the following parameters are considered for each region:

- Annual solar production value;

- Average electricity escalation rate;

- Euribor Interest rate;

- Inflation rate

- Electricity tariff;

- Battery injection tariff;

- PV system and Battery bank initial cost;

- Maintenance and Operations cost;

- Inverter substitution cost;

- Battery bank substitution cost;

- Degradation rate of the PV modules.

All three regions in Portugal differ in solar production values, PV system initial investments, electricity tariffs, and VAT tax rates. While they all share the same maintenance and operations rate, inverter replacement rate, battery bank replacement rate, electricity evolution rate, the Euribor interest rate and the inflation rate.

The following subsections describe how the parameters mentioned above are obtained to then be presented in the results section.

\section{3) Economical parameters}

The electricity price escalation rate is used in this work to roughly predict the electricity prices for the next 25 years by calculating an average escalation rate of the electricity prices from the past 25 years [24]. The grid injection price in Portugal is based on the OMIE values and in order to predict the OMIE price over the next 25 years, an average grid injection rate is calculated based on the prices of the past 4 years (since 2011) [25]. In order to predict the Euribor interest rate for the next 25 years, an average is calculated based on the past 16 years (Eurozone).

The inflation rate is also considered in this work in order to obtain realistic values for the maintenance labour and operations costs during the 25-year period of the investment.

The electricity tariffs presented in this work, are the ones practiced at the present moment in all the cities (year 2015) [26]-[28].

Only for scenarios 1 and 2, the mono and bi-hourly tariffs are associated to the $1 \mathrm{~kW}$ and $3 \mathrm{~kW}$ PV system since both of them are frequently used in the residential sector while the $5 \mathrm{~kW}$ PV system will be associated only to the tri-hourly tariff. For all the other scenarios, all the PV systems linked to a battery bank are associated to a mono-hourly tariff since this tariff has the highest off-peak tariff price out of all the tariffs.

Self-consumption savings are calculated by associating the hourly electricity tariffs to the amount of solar production that is produced by a given PV system. In order to correctly allocate the solar production to each hourly section (on-peak, regular and off-peak) and calculate the amount of money saved with self-consumption, a portion of the total annual production is associated to the on-peak, regular and off-peak hours of the hourly tariffs according to the summer and winter months, as shown in Table II [29].

There is an online PV system solar production profile published by ERSE in which the dataset has a 15 minute sampling time and is used to calculate the portion rate of each hourly tariff for both summer and winter months [30]. Overall, the portion percentages of the on-peak hours are higher in the islands than in the mainland therefore concluding that the islands are prone to having higher savings than in the mainland. The mono-hourly tariff portion percentage is not presented in Table II since the tariff is the same in all hours of the day.

TABLE II: PORTION PERCENTAGES OF THE HOURLY TARIFFS

\begin{tabular}{c|cc|cc|cc}
\hline \hline \multirow{2}{*}{} & \multicolumn{2}{|c|}{ Mainland } & \multicolumn{2}{c}{ Madeira } & \multicolumn{2}{c}{ Azores } \\
\cline { 2 - 7 } & Winter & Summer & Win & Sum & Winter & Summer \\
\hline \multicolumn{7}{c}{ Bi-hourly tariff } \\
\hline on-peak & $77 \%$ & $78 \%$ & $96 \%$ & $95 \%$ & $99 \%$ & $99 \%$ \\
\hline off-peak & $23 \%$ & $22 \%$ & $4 \%$ & $5 \%$ & $1 \%$ & $1 \%$ \\
\hline \multicolumn{7}{|c}{ Tri-hourly tariff } \\
\hline on-peak & $22 \%$ & $19 \%$ & $20 \%$ & $26 \%$ & $18 \%$ & $22 \%$ \\
\hline regular & $56 \%$ & $59 \%$ & $76 \%$ & $70 \%$ & $81 \%$ & $77 \%$ \\
\hline off-peak & $23 \%$ & $22 \%$ & $4 \%$ & $5 \%$ & $1 \%$ & $1 \%$ \\
\hline \hline
\end{tabular}

For the investment costs to be realistic, at least three quotes from different companies from each region were received and an average investment value for each region is calculated. All quotes are turnkey solutions, which include all the components of the PV system, battery bank, mounting structure, delivery, and installation. This is not an easy process to achieve since many companies in Portugal are not familiar with the new self-consumption regulations. 


\section{4) Degradation rate}

The degradation phenomena of the modules reduces the efficiency of the system over time [23] and consequently, the predicted solar production of the PV system and its economic payback period analysis is affected by this issue. The methodology guidelines on the lifecycle assessment of PV systems statements, recommends considering a linear degradation, reaching $80 \%$ of the initial efficiency at the end of a 30 years lifetime (i.e., $0.7 \%$ per year) [23], [31]. The $\mathrm{PV}$ degradation in this work is assumed as $0.7 \%$ year.

\section{5) Operating and maintenance cost}

The operation and maintenance cost (O\&M) is estimated between $1-3 \%$ of the initial investment per year according to [32]-[35]. Table III presents the O\&M costs according to the different PV systems. The profit of the investment considers the inverter replacement costs as well as the costs associated with the operations and maintenance (O\&M) along the system's lifespan.

\section{RESULTS AND DISCUSSION}

The results obtained from the methodology section are presented in this section.

All the parameters presented in Table III are common to all regions while Table IV presents all parameters that are different in all regions.

Table IV shows how Madeira Island has the highest solar production values while the Azores Island has the lowest, for the cities under consideration. There are three types of PV system investments, where the first refers to the PV system used only for self-consumption without being connected to a battery bank (scenarios 1 and 2). The second refers to the investment of a PV system connected to a leadacid battery bank and the third investment is associated to a PV system linked to a gel battery bank.

The IRR, Profitability Index and DPBP are calculated by using the values presented in Table IV together with the values in Table III for the different PV system sizes of each region for each of the six different scenarios.

TABLE III: INFORMATION COMMON TO ALL REGIONS IN PORTUGAL

\begin{tabular}{l|c|c}
\hline \hline \multicolumn{2}{c}{ Parameter Description } & Value \\
\hline \multirow{2}{*}{ Maintenance and operations rate } & $\mathbf{1 k W}$ & $3 \%$ \\
\cline { 2 - 3 } & $\mathbf{3 k W}$ & $1.5 \%$ \\
\cline { 2 - 3 } & $\mathbf{5 k W}$ & $1.5 \%$ \\
\hline \multirow{2}{*}{ Inverter Replacement cost rate } & $\mathbf{1 k W}$ & $15.0 \%$ \\
\cline { 2 - 3 } & $\mathbf{3 k W}$ & $13.0 \%$ \\
\cline { 2 - 3 } & $\mathbf{5 k W}$ & $10.0 \%$ \\
\hline Grid injection Tariff based on OMIE $\mathbf{2 0 1 5}$ & $0.0377 €$ \\
\hline Grid injection Evolution rate & $4.250 \%$ \\
\hline Electricity Evolution rate & $2.428 \%$ \\
\hline Euribor Interest rate & $2.644 \%$ \\
\hline Inflation Rate & $1.48 \%$ \\
\hline \hline
\end{tabular}

In general, the initial investment costs for PV systems without battery banks are the lowest in the mainland and highest in the Madeira Island and the bigger the PV system size, the cheaper the investment per Watt in all the regions. The mainland practices the highest hourly tariffs and the lowest is practiced in the Azores Island. The VAT tax rate is excluded from all prices presented in Table IV.

Breakeven takes place when the profitability index is equal to 1.00 , which is on the same year as the DPBP, which takes place usually before the $12^{\text {th }}$ year in this paper and the profit is accumulated from there onwards. The investment is considered to be good when the investment is doubled $(\mathrm{PI}=2.00)$ before the end of the 25 year period.

TABLE IV: 1KW, 3KW AND 5KW PV SYSTEM INFORMATION

\begin{tabular}{|c|c|c|c|c|c|c|c|c|}
\hline & & & \multirow{2}{*}{\multicolumn{2}{|c|}{$\frac{\text { Mainland - Aljustrel }}{1529}$}} & \multirow{2}{*}{\multicolumn{2}{|c|}{$\begin{array}{c}\text { Madeira Island - Calheta } \\
1566\end{array}$}} & \multirow{2}{*}{\multicolumn{2}{|c|}{$\begin{array}{c}\text { Azores Island - Vila do Porto } \\
1409\end{array}$}} \\
\hline & \multicolumn{2}{|c|}{$1 \mathrm{~kW}$} & & & & & & \\
\hline PV system & \multicolumn{2}{|c|}{ 3kW } & \multicolumn{2}{|c|}{4577} & \multicolumn{2}{|c|}{4687} & \multicolumn{2}{|c|}{4218} \\
\hline Solar Production (kWh) & $5 \mathbf{k}$ & & \multicolumn{2}{|c|}{7610} & \multicolumn{2}{|c|}{7793} & \multicolumn{2}{|c|}{7014} \\
\hline \multirow{2}{*}{$\begin{array}{l}\text { PV system Investment } \\
\text { for self-consumption }\end{array}$} & \multicolumn{2}{|c|}{$3 \mathbf{k W}$} & $6,529.27 €$ & $2.18 € / \mathrm{W}$ & $6,955.77 €$ & $2.32 € / \mathrm{W}$ & $6,353.85 €$ & $2.12 € / \mathrm{W}$ \\
\hline & \multicolumn{2}{|c|}{$5 \mathrm{~kW}$} & $10,225.56 €$ & $2.05 € / \mathrm{W}$ & $10,262.65 €$ & $2.05 € / \mathrm{W}$ & $9,275.10 €$ & $1.86 € / \mathrm{W}$ \\
\hline \multirow{3}{*}{$\begin{array}{c}\text { Lead-Acid Battery } \\
\text { Bank + PV system } \\
\text { Investment }\end{array}$} & \multicolumn{2}{|c|}{$1 \mathrm{~kW}$} & $2,486.37 €$ & $2.49 € / \mathrm{W}$ & $3,210.17 €$ & $3.21 € / \mathrm{W}$ & $3,156.78 €$ & $3.16 € / \mathrm{W}$ \\
\hline & \multicolumn{2}{|c|}{$3 \mathbf{k W}$} & $7,406.46 €$ & $2.47 € / \mathrm{W}$ & $8,161.83 €$ & $2.72 € / \mathrm{W}$ & $7,710.39 €$ & $2.57 € / \mathrm{W}$ \\
\hline & \multicolumn{2}{|c|}{$5 \mathrm{~kW}$} & $11,919.17 €$ & $2.38 € / \mathrm{W}$ & $11,969.17 €$ & $2.39 € / \mathrm{W}$ & $11,256.32 €$ & $2.25 € / \mathrm{W}$ \\
\hline \multirow{3}{*}{$\begin{array}{c}\text { Gel Battery Bank + PV } \\
\text { system Investment }\end{array}$} & \multicolumn{2}{|c|}{$1 \mathrm{~kW}$} & $2,620.96 €$ & $2.62 € / W$ & $3,407.30 €$ & $3.41 € / W$ & $3,353.91 €$ & $3.35 € / \mathrm{W}$ \\
\hline & \multicolumn{2}{|c|}{$3 \mathbf{k W}$} & $7,731.39 €$ & $2.58 € / \mathrm{W}$ & $8,552.08 €$ & $2.85 € / \mathrm{W}$ & $8,100.64 €$ & $2.70 € / \mathrm{W}$ \\
\hline & \multicolumn{2}{|c|}{$5 \mathbf{k W}$} & $12,479.42 €$ & $2.50 € / \mathrm{W}$ & $12,536.92 €$ & $2.51 € / \mathrm{W}$ & $11,824.07 €$ & $2.36 € / \mathrm{W}$ \\
\hline \multirow{5}{*}{ Electricity tariff Price } & \multicolumn{2}{|c|}{ Mono-hourly } & \multicolumn{2}{|c|}{$0.1587 €$} & \multicolumn{2}{|c|}{$0.1609 €$} & \multicolumn{2}{|c|}{$0.1624 €$} \\
\hline & \multirow{2}{*}{ Bi-hourly } & On-Peak & \multicolumn{2}{|c|}{$0.1890 €$} & \multicolumn{2}{|c|}{$0.1843 €$} & \multicolumn{2}{|c|}{$0.1878 €$} \\
\hline & & Off-Peak & \multicolumn{2}{|c|}{$0.0978 €$} & \multicolumn{2}{|c|}{$0.0979 €$} & \multicolumn{2}{|c|}{$0.0990 €$} \\
\hline & & On-Peak & 0.21 & & & & 0.2 & \\
\hline & & Off-Peak & 0.09 & & & & 0.0 & \\
\hline VAT t & $x$ rate & & 23 & & & & & \\
\hline
\end{tabular}

Table $\mathrm{V}$ presents the economic analysis of the PV systems without batteries in scenario $1(100 \%$ selfconsumption regime) and scenario $2 \quad(70 \%$ selfconsumption). It is verified that the bi-hourly tariffs offer higher profit on the investment when compared to the monohourly tariffs in all cases. Only for the $3 \mathrm{~kW}$ (all three regions) and $5 \mathrm{~kW}$ (only islands) $\mathrm{PV}$ systems, is the investment doubled.

The 5kW PV system under the tri-hourly tariffs in the mainland does not make double the investment while more than double the investment can be made in the islands with the same PV system size. This observation clearly demonstrates how having higher portion percentages in the on-peak hours, as shown in Table II can be an advantage even though the investment costs are higher in the islands than in the mainland.

In general, the profitability index value in all regions and situations manages to be slightly higher than breakeven 
value $(P I=1)$ by the end of the 25 year period except for the $1 \mathrm{~kW}$ PV systems in scenario 2. The mainland presents the highest PI values for the $1 \mathrm{~kW}$ and $3 \mathrm{~kW}$ (mono-hourly) PV systems but the lowest for the $3 \mathrm{~kW}$ (bi-hourly) and 5kW PV systems. This reflects how the hourly portions (on-peak regular and off-peak) practiced in the mainland do not coincide with the peak hours of the PV system and causes a great disadvantage on the solar producers, even though the bi and tri-hourly tariff prices are higher than in the islands.

In order to double the investment mentioned in this paper, the IRR has to be a little under $10 \%$ and the DPBP has to be just under 12 years. In all situations analysed in Table V, the IRR values are always higher than the Euribor interest rate $(2.644 \%)$ assumed for this work. This indicates that investing in a PV system without batteries under a selfconsumption regime is good all over Portugal.

As mentioned before, the registry costs for grid injection permission is too high for the $1 \mathrm{~kW}$ PV systems, therefore it is assumed in this work that the $1 \mathrm{~kW}$ PV system grid injection tariff is at $0 € / \mathrm{kWh}$ and in scenario 2 there is always a $30 \%$ loss of solar energy. The $1 \mathrm{~kW}$ PV system presents the worst results throughout Table V. This information is highly relevant as the $1 \mathrm{~kW}$ PV system is the one that most households in Portugal should be able to acquire for selfconsumption since under the instantaneous net-metering scheme they cannot take full advantage of higher power.

In scenario $2,70 \%$ of the solar energy is used for selfconsumption and the rest is injected into the grid. Overall, the scenario 2 results indicate that injecting the surplus solar energy into the grid is not profitable enough to make double the investment by the end of 25 years in any of the cases.

TABLE V: THE IRR, PI, AND DPBP OF SCENARIOS 1 AND 2 - PV SYSTEM WITHOUT BATTERIES

\begin{tabular}{c|ccc|ccc}
\hline \hline & 100\% self-consumption & \multicolumn{1}{c}{ 70\% self-consumption } \\
\hline & IRR & PI & DPBP & IRR & PI & DPBP \\
\hline & \multicolumn{7}{c}{ 1kW - Mono-hourly tariff } \\
\hline Mainland & $7.68 \%$ & 1.74 & 14 & $2.22 \%$ & 0.95 & $>25$ \\
\hline Madeira & $5.97 \%$ & 1.44 & 16 & $0.42 \%$ & 0.76 & $>25$ \\
\hline Azores & $4.42 \%$ & 1.24 & 21 & $-1.06 \%$ & 0.60 & $>25$ \\
\hline \multicolumn{7}{c}{$\mathbf{1 k W}$ - Bi-hourly tariff } \\
\hline Mainland & $9.36 \%$ & 1.97 & 12 & $3.68 \%$ & 1.13 & 22 \\
\hline Madeira & $8.14 \%$ & 1.77 & 13 & $2.55 \%$ & 0.99 & $>25$ \\
\hline Azores & $6.66 \%$ & 1.57 & 15 & $1.22 \%$ & 0.83 & $>25$ \\
\hline \multicolumn{7}{|c}{ 3kW - Mono-hourly tariff } \\
\hline Mainland & $9.14 \%$ & 1.94 & 12 & $5.52 \%$ & 1.38 & 17 \\
\hline Madeira & $8.77 \%$ & 1.88 & 13 & $5.18 \%$ & 1.33 & 18 \\
\hline Azores & $8.69 \%$ & 1.86 & 13 & $5.14 \%$ & 1.33 & 18 \\
\hline \multicolumn{7}{c}{ 3kW - Bi-hourly tariff } \\
\hline Mainland & $9.69 \%$ & 2.03 & 12 & $5.97 \%$ & 1.45 & 16 \\
\hline Madeira & $10.80 \%$ & 2.22 & 11 & $6.82 \%$ & 1.57 & 15 \\
\hline Azores & $10.86 \%$ & 2.23 & 11 & $6.89 \%$ & 1.59 & 15 \\
\hline \multicolumn{7}{|c}{$\mathbf{5 k W}$ - Tri-hourly tariff } \\
\hline Mainland & $7.98 \%$ & 1.75 & 14 & $5.06 \%$ & 1.32 & 18 \\
\hline Madeira & $12.64 \%$ & 2.56 & 9 & $8.74 \%$ & 1.89 & 13 \\
\hline Azores & $12.56 \%$ & 2.55 & 9 & $8.68 \%$ & 1.88 & 13 \\
\hline \hline
\end{tabular}

Table VI presents the economic analysis of the PV systems with batteries under $100 \%$ self-consumption regime that include scenarios 3 (lead-acid) and 4 (gel). The gel battery bank is very expensive, resulting that in general, none of the PV systems linked to a gel battery bank is considered a good investment since the PI values presented in Table VI are lower than 2.00. All the IRR values are just below $7 \%$ and the DPBP is higher than 16 years. These calculations consider the inverter replacement (every 10 years) and battery bank replacement (every 8 years for leadacid and every 12 years for gel), therefore adding to the expenses during the 25-year period.

Overall, the lead-acid battery scenario presents better results compared to the gel battery scenario. The $1 \mathrm{~kW}$ PV system linked to the lead-acid batteries is not a good investment in any situation (city or type of battery bank). The $3 \mathrm{~kW}$ PV system presents the best results in the mainland. Madeira Island presents the highest results for the $5 \mathrm{~kW}$ PV system, due to the high mono-hourly tariffs that are practiced even though the investment cost is slightly higher than in the mainland. This observation demonstrates how the high mono-hourly tariffs play a greater role than the investment cost and the solar radiation values. The Azores Island presents very low values because of the low solar radiation even though it has a lower investment cost than the Madeira Island.

TABLE VI: IRR, PI, AND DPBP VALUES FOR SCENARIOS 3 AND 4 PV SYSTEM WITH BATTERIES (100\% SELF-CONSUMPTION)

\begin{tabular}{c|ccc|ccc}
\hline \hline \multirow{2}{*}{} & \multicolumn{2}{|c}{ Scenario 3 - Lead-Acid } & \multicolumn{3}{|c}{ Scenario 4 - Gel } \\
\cline { 2 - 7 } & IRR & PI & DPBP & IRR & PI & DPBP \\
\cline { 2 - 7 } & \multicolumn{7}{c}{ 1kW PV system - Mono-hourly tariff } \\
\hline Mainland & $2.74 \%$ & 1.01 & 25 & $1.58 \%$ & 0.89 & $>25$ \\
\hline Madeira & $-0.83 \%$ & 0.65 & $>25$ & $-2.24 \%$ & 0.54 & $>25$ \\
\hline Azores & $-2.70 \%$ & 0.51 & $>25$ & $-4.38 \%$ & 0.41 & $>25$ \\
\hline \multicolumn{7}{c}{ 3kW PV system - Mono-hourly tariff } \\
\hline Mainland & $4.91 \%$ & 1.27 & 18 & $4.00 \%$ & 1.16 & 21 \\
\hline Madeira & $4.17 \%$ & 1.18 & 21 & $3.23 \%$ & 1.07 & 22 \\
\hline Azores & $3.25 \%$ & 1.07 & 22 & $2.21 \%$ & 0.95 & $>25$ \\
\hline \multicolumn{7}{|c}{$\mathbf{5 k W ~ P V ~ s y s t e m ~ - ~ M o n o - h o u r l y ~ t a r i f f ~}$} \\
\hline Mainland & $5.91 \%$ & 1.41 & 17 & $5.02 \%$ & 1.29 & 18 \\
\hline Madeira & $6.44 \%$ & 1.48 & 16 & $5.55 \%$ & 1.36 & 18 \\
\hline Azores & $5.64 \%$ & 1.37 & 17 & $4.67 \%$ & 1.24 & 19 \\
\hline \hline
\end{tabular}

Table VII has the same information as Table VI except that $70 \%$ of the solar energy is used for self-consumption and the rest is injected into the grid except for the $1 \mathrm{~kW}$ PV system, just as explained before.

Overall, the results indicate that grid injection is not as profitable as practicing a $100 \%$ self-consumption regime and is not advised due to the poor results and once more, the $1 \mathrm{~kW}$ PV system presents the worst results.

TABLE VII: IRR, PI, AND DPBP VALUES FOR SCENARIOS 5 AND 6 PV SYSTEM WITH BATTERIES (70\% SELF-CONSUMPTION)

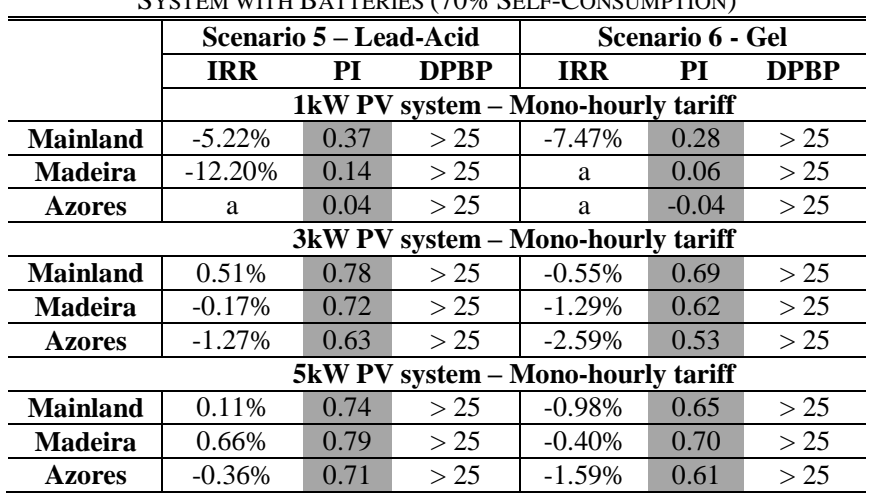

a - The IRR calculation for accumulated negative cash flows resulted in a very large absolute number that is not represented by excel. Nevertheless, the conclusion should be that the investment is not viable. 
Out of all the scenarios, the $100 \%$ self-consumption scenarios for both PV system situations (with and without battery banks) present the best values and since the $100 \%$ self-consumption scenario presents better results than the $70 \%$ self-consumption scenario, grid injection is not advised. The PV systems without batteries present better results than the PV systems that are linked to battery banks due to the high replacement costs (inverters and battery banks) that are present during the 25 -year period.

\section{CONCLUSION}

One of the main conclusions we can draw from the recent changes in the Portuguese regulations is that the PV system should now be dimensioned for instantaneous consumption only since the return generated from selling to the grid is much lower then the one obtained from self-consumption.

Analysing the results we can see that most profit can be obtained from the island areas for $3 \mathrm{~kW}$ PV system without batteries.

The $3 \mathrm{~kW}$ PV system is more profitable under a bi-hourly tariff.

In the mainland, lower prices are available for the initial investment and they also have higher hourly electricity tariffs. Nevertheless, the islands present better results due to the fact that the timetable of the hourly tariffs in the islands capture more of the solar production peak hours than the timetable set for the mainland.

In general, it can be concluded that $100 \%$ selfconsumption regime is more profitable than a $70 \%$ selfconsumption regime, independently of the use of batteries.

Considering the batteries, the lead-acid option presented better results because the investment costs are lower. In this type of solution, we took into account not only the replacement of the inverter (every 10 years) but also the replacement of the battery bank. Moreover, the latter replacement is very expensive over time. The lead-acid battery replacement should be done every 8 years and the gel battery replacement at every 12 years. Considering the longevity it was expected that the lead-acid battery present worse results, but in practice the gel batteries are very expensive and the longer replacement time does not present any advantage.

Overall, the PV system linked to battery banks are not considered a good investment since none of the scenarios present a result with a $100 \%$ profit over the investment period.

Looking at the installed power, the $1 \mathrm{~kW}$ option is not profitable in any PV system scenario and in any city. Considering the most common households that have an annual consumption that can only support a $1 \mathrm{~kW}$ PV system under an instantaneous net-metering scheme, the present set of regulations is very negative to the development of this type of installations, since it only has a breakeven after twelve years, which is not an attractive investment situation. In principle, only few households in Portugal have a consumption level during the daytime to absorb all the energy produced by a $3 \mathrm{~kW}$ and a $5 \mathrm{~kW}$ PV system, which makes the 2020 Kyoto Protocol target harder to achieve.

This situation can change if the PV system initial costs continue to decrease and, at the same time electricity prices increase. In general, these two parameters, together with the solar radiation values, play a big role on the possibility to double the investment in a period of 25 years.

\section{ACKNOWLEDGMENT}

The authors would like to acknowledge the Portuguese Foundation for Science and Technology for their support through project PEst-OE/EEI/LA0009/2011.

Also acknowledged is the Funding Program + Conhecimento II: Incentive System to Research and Technological Development and Innovation of Madeira Region II, through the project "Smart Solar" - MADFDR01-0190-FEDER-000015.

\section{REFERENCES}

[1] S. R. Abreu, M. Leça, X. Chen, and F. M. Dias, "On the current payback time for small investors in the photovoltaic systems in the region of Madeira," in Proc. the 11th Portuguese Conference on Automatic Control, 2015, pp. 375-384.

[2] Ordinance $363 / 2007$ de 2 de Novembro, Estabelece o Regime Jurídico Aplicável à Produção de Electricidade por Unidades de Micro Produção, Diário da República, Nov. 2007, no. 211, pp. 79787984.

[3] M. Gaëtan et al., "Global market outlook for photovoltaics 20142018," European Photovoltaic Industry Association, 2013.

[4] Ordinance 153/2014 de 20 de Outubro, Produção de Energia Distribuída, Diário da República, Oct. 2014, no. 202, pp. 5298-5311.

[5] B. B. B. Mckeon, J. Furukawa, and S. Fenstermacher, "Advanced lead - Acid batteries and the development of grid-scale energy storage systems," Proceedings of the IEEE, vol. 102, no. 6, pp. 951963, 2014

[6] L. Torcheux and P. Lailler, "New electrolyte formulation for low cost cycling lead acid batteries," Journal of Power Sources, vol. 95, no. 12, pp. 248-254, 2001.

[7] J. L. Bernal-Agustín and R. Dufo-López, "Economical and environmental analysis of grid connected photovoltaic systems in Spain," Renewable Energy, vol. 31, no. 8, pp. 1107-1128, Jul. 2006.

[8] A. Audenaert, L. De Boeck, S. De Cleyn, S. Lizin, and J. Adam, "An economic evaluation of photovoltaic grid connected systems (PVGCS) in Flanders for companies: A generic model," Renewable Energy, vol. 35, no. 12, pp. 2674-2682, 2010.

[9] A. Campoccia, L. Dusonchet, E. Telaretti, and G. Zizzo, "An analysis of feed'in tariffs for solar PV in six representative countries of the European Union," Solar Energy, vol. 107, pp. 530-542, 2014.

[10] T. Lang, E. Gloerfeld, and B. Girod, "Don't just follow the sun - A global assessment of economic performance for residential building photovoltaics," Renewable and Sustainable Energy Reviews, vol. 42, pp. 932-951, 2015

[11] C. Obaidullah. (2015). Profitability index, formula, decision rule, example. [Online]. Available: http://accountingexplained.com/managerial/capitalbudgeting/profitability-index

[12] R. Aguiar and R. Coelho. (2012). Manual SolTerm V5.1. Lisbon: LNEG. [Online]. Available: http://www.lneg.pt/download/5595/Manual_SolTerm_5.1.4.pdf

[13] Retscreen International, "Retscreen - Renewable energy project analysis software," 2014.

[14] P. Stackhouse and J. Kusterer. (2014). Surface meteorology and solar energy. [Online]. Available: https://eosweb.larc.nasa.gov/sse/

[15] A. Purvins, I. Papaioannou, and L. Debarberis, "Application of battery-based storage systems in household-demand smoothening in electricity-distribution grids," Energy Conversion and Management, vol. 65 , pp. 272-284, 2013.

[16] PV Magazine, "Tested: Solar world sun module plus SW 245 poly," 2013.

[17] G. Granata, F. Pagnanelli, E. Moscardini, T. Havlik, and L. Toro, "Recycling of photovoltaic panels by physical operations," Solar Energy Materials and Solar Cells, vol. 123, pp. 239-248, 2014.

[18] K. Zweibel, "Should solar photovoltaics be deployed sooner because of long operating life at low, predictable cost?" Energy Policy, vol. 38, no. 11, pp. 7519-7530, 2010.

[19] Sol Distribution. (2012). SMA solar next innovations catalogue. [Online]. Available: http://www.sol-distribution.com.au/SMAInverters/SMA-Solar-Technology-Next-Innovations-Catalogue.pdf 
[20] Victron Energy. (2000). MultiPlus inverter / charger. [Online]. Available:

http://www.victronenergy.com/upload/documents/DatasheetMultiPlus-inverter-charger--800VA-\%E2\%80\%93-5kVA-EN.pdf

[21] J. Peng, L. Lu, and H. Yang, "Review on life cycle assessment of energy payback and greenhouse gas emission of solar photovoltaic systems," Renewable and Sustainable Energy Reviews, vol. 19, pp. 255-274, 2013.

[22] M. Mani and R. Pillai, "Impact of dust on solar photovoltaic (PV) performance: Research status, challenges and recommendations," Renewable and Sustainable Energy Reviews, vol. 14, no. 9, pp. 3124$3131,2010$.

[23] V. Fthenakis et al., "Methodology guidelines on life cycle assessment of photovoltaic electricity," IEA PVPS Task 12, 2011.

[24] Eurostat. (2015). Electricity prices by type of user. [Online]. Available: http://ec.europa.eu/eurostat/web/products-datasets/tenO011

[25] OMIE - The Spanish Division of the Iberian Energy Market Operator. (2013). Energy market results. [Online]. Available: http://www.omie.es/files/flash/ResultadosMercado.swf

[26] ERSE. (2015). Tarifas de venda a clientes finais em portugal continental. [Online]. Available: http://www.erse.pt/pt/electricidade/tarifaseprecos/2015/Documents/Pr ecosTVCF\%20PTCont_2015.pdf

[27] ERSE. (2015). Tarifas de venda a clientes finais nos açores. [Online]. Available:

http://www.erse.pt/pt/electricidade/tarifaseprecos/2015/Documents/Pr ecos.TVCF.RAA2015.pdf

[28] ERSE. (2015). Tarifas de venda a clientes finais na madeira. [Online]. Available:

http://www.erse.pt/pt/electricidade/tarifaseprecos/2015/Documents/Pr ecos.TVCF.RAM2015.pdf

[29] ERSE. Ciclo Horário. [Online]. Available: http://www.erse.pt/consumidor/electricidade/querosercliente/tenholig acaoarede/Documents/Documento_CiclosHorários_Electricidade.pdf

[30] ERSE. (2015). Microproduction annual production profile. [Online]. Available:

http://www.erse.pt/pt/electricidade/regulamentos/relacoescomerciais/ Documents/SubRegulamenta\%C3\%A7\%C3\%A3o/Anexo

[31] Retscreen developers. (2014). Retscreen software help. [Online]. Available: http://www.retscreen.net/

[32] Media Triami. Euribor interest rates. [Online]. Available: http://www.euribor-rates.eu/euribor-2004.asp?i1=15\&i2=1

[33] A. Campoccia, L. Dusonchet, E. Telaretti, and G. Zizzo, "Comparative analysis of different supporting measures for the production of electrical energy by solar PV and wind systems: Four representative European cases," Solar Energy, vol. 83, no. 3, pp. 287297, 2009.

[34] P. Koner, V. Dutta, and K. Chopra, "A comparative life cycle energy cost analysis of photovoltaic and fuel generator for load shedding application," Solar Energy Materials and Solar Cells, vol. 60, no. 4, pp. 309-322, 2000.

[35] F. Sick and T. Erge, Photovoltaics in Buildings, London: James \& James (Science Publishers) Ltd., 1996.

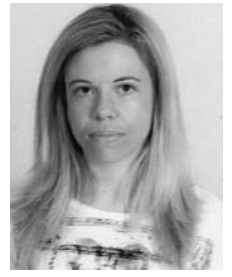

Sandy Rodrigues received her master's degree in telecommunications and networks from University of Madeira, Portugal in 2009, she is currently enrolled in a $\mathrm{PhD}$ in the same university since 2013, and is currently working in a research project called "Smart Solar" at the Madeira Interactive Technologies Institute. Her research interests include renewable energy and artificial neural networks.

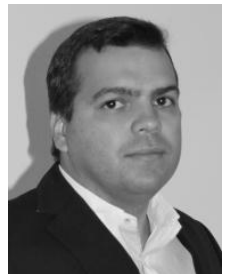

Fábio Faria received his master's degree in renewable energy, electric conversion and sustainable use from the Faculty of Science and Technology of the Universidade Nova de Lisboa, Portugal, in 2012 and currently works in a research project called "Smart Solar" at the Madeira Interactive Technologies Institute. His research interests include renewable energy.

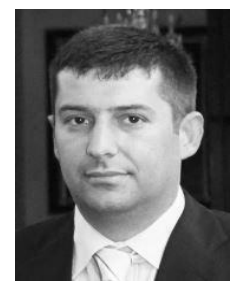

Nuno Filipe Vieira Cafôfo received his degree in electrical and computer engineering from University of Coimbra, Portugal in 2005. In the last 5 years, he is working in renewable energy, in household PV systems.

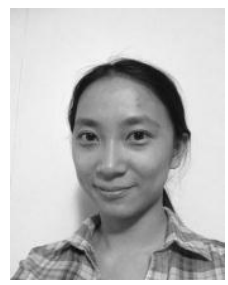

Xiaoju Chen received her master of science degree with major in civil and environmental engineering from Carnegie Melon University in Pittsburgh, United States in 2012 and is currently pursuing her $\mathrm{PhD}$ in civil and environmental engineering at the same university and she is also a researcher at the Green Design Institute.

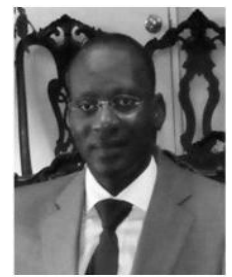

Herlander Mata-Lima received his MSc degree in environmental management policies from the New University of Lisbon in 2004, his $\mathrm{PhD}$ degree in engineering sciences from University of Lisbon in 2006, and since 2007, he is a researcher at CERENA - Instituto Superior Técnico, University of Lisbon, Portugal. His research focus on the areas of environment, development and sustainability.

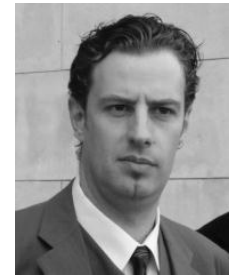

Fernando Morgado-Dias received his master's degree in microelectronics from University Joseph Fourier in Grenoble, France in 1995 and his PhD degree from University of Aveiro, Portugal, in 2005 and is currently an assistant professor at University of Madeira and Researcher at Madeira Interactive Technologies Institute. His research interests include renewable energy and artificial neural networks. 